\title{
Synthesis, Charecterization of a New 16 A, S, C-HBPAE-b-PCL Copolymers and the Mechanical Properties of the Copolymer- Cement Composites
}

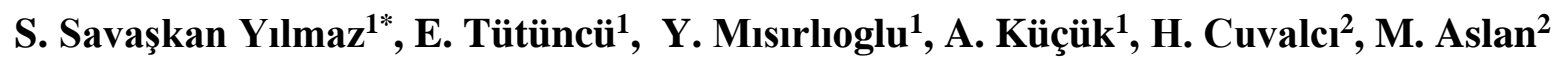 \\ ${ }^{1}$ Department of Chemistry, Karadeniz Technical University \\ 61080, Trabzon, Turkey \\ ${ }^{2}$ Metallurgical and Materials Engineering, Karadeniz Technical University \\ 61080, Trabzon, Turkey
}

\begin{abstract}
The new 16-Arms, Star, Coil-HBPAE- b-PCL(16 A, S, C-HBPAE-b-PCL) copolymers was synthesized hyperbranched poly amide-ester (HBPAE) as the macroinitiator and epsilon caprolactone ( $\varepsilon$-CL) monomer by using Ring Opening(ROP). Characterisation of the polymers was achieved by FTIR, ${ }^{1} \mathrm{H}$ NMR GPC, MS, SEM, AFM, TGA, DSC, techniques and MTS Criterion brand 45 model mechanical testing. The new 16 A, S, C-HBPAE-b-PCL-OPC composites containing 16 A, S, C-HBPAE-b-PCL additive were prepared for the purpose of improve of Ordinary Portland Cement $(\mathrm{OPC})$ properties. The compressive strength and the bending resistance tests of the composites were investigated.The cement mortar samples prepared for the experiments were produced in the laboratories of Karadeniz Technical University in accordance with TS EN 196-1, TS EN ISO 15630-1 and TS EN ISO 75001 "Cement test methods" standard.
\end{abstract}

Keywords: Epsilon Caprolactone ( $\varepsilon-\mathrm{CL})$ Copolymer, Ring Opening(ROP), Polymer-Cement Composites, Impact Resistance, Mechanical Strength.

\section{Introduction}

The new 16 A, S, C-HBPAE-b-PCL copolymers was synthesized HBPAE as the macroinitiator[1, 2, 3, 4, 5] and $\varepsilon$ CL monomer by using ROP. PPCC (Polymer portland cement concrete); coatings, cobble stones, combined water structures, decorative surface coatings, abrasion-resistant lining, repair materials and bridging materials. The most widely used is latex modified concrete (LMC), and concrete is the concrete in which polymer emulsions called latex are used instead of part of the mixture water. Polymer-impregnated concrete is concrete produced by impregnating a hardened Portland cement concrete with a monomer and then polymerizing it [6, 7]. In a study by Okada and Ohama, the mortars modified with polymers with the trade names SBR-EVA and PAE. It has been reported to be used in a variety of applications such as coating, waterproofing, adhesive decorative coatings, surface finishing materials, abrasion resistant deck coatings [8].

\section{Experimental}

\subsection{Synthesis of AB2 Monomer}

AB2 monomer was synthesized by using maleic anhydride (MA) and Diethanolamine (DEA) solution in $100 \mathrm{ml}$ distilled chloroform at $25^{\circ} \mathrm{C}$. The reaction mixture in the Schlenk system was submerged in oil bath at $60^{\circ} \mathrm{C}$. The final

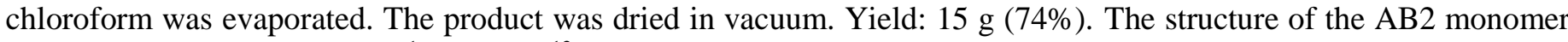
was investigated using FT-IR, ${ }^{1} \mathrm{H}-\mathrm{NMR},{ }^{13} \mathrm{C}-\mathrm{NMR}$, TGA and mass spectroscopy.

\subsection{Synthesis of Highly Branched PoliAmino-Ester (HBPAE) Macroinitiator}

HBPAE macroinitiator was synthesized by AB2 monomer, pentaerythrol and polythiosulfonic acid (p-TSA). Yield: $68 \mathrm{~g}(71.7 \%) .3360 \mathrm{~cm}^{-1}(-\mathrm{OH}), 2945 \mathrm{~cm}^{-1}$ (Aliphatic-CH), $1718 \mathrm{~cm}^{-1}(\mathrm{C}=\mathrm{O}), 1172 \mathrm{~cm}^{-1}(\mathrm{C}-\mathrm{O})$ in the FT-IR spectrum of the synthesized macroinitiator. ${ }^{1} \mathrm{H}-\mathrm{NMR}$ (DMSO-d $\left.\mathrm{d}_{6}, \mathrm{ppm}\right)$ of HBPAE macroinitiator:2.68 $\left(\mathrm{s}, 2 \mathrm{H}, \mathrm{CH}_{2}\right), 2.84(\mathrm{~s}, 2 \mathrm{H}$, $\left.\mathrm{CH}_{2}\right), 2.94\left(\mathrm{t}, 4 \mathrm{H}, 2 \mathrm{CH}_{2}-\mathrm{N}\right), 3.31\left(\mathrm{~s}, 2 \mathrm{H}, \mathrm{CH}_{2}+\mathrm{H}_{2} \mathrm{O}\right), 3.47(\mathrm{~d}, 2 \mathrm{H}, \mathrm{OH}, j=10 \mathrm{MHz}), 3.60\left(\mathrm{t}, 4 \mathrm{H}, 2 \mathrm{CH}_{2}-\mathrm{OH}\right), 6.00(\mathrm{~s}, 1 \mathrm{H}$, $\left.\mathrm{CH}_{2}\right), 6.35(\mathrm{~m}, 1 \mathrm{H}, \mathrm{CH}), 6.42(\mathrm{~s}, 1 \mathrm{H}, \mathrm{CH}), 6,64(\mathrm{~m}, 1 \mathrm{H}, \mathrm{CH}) \cdot{ }^{13} \mathrm{C}$ NMR $\left.\left(\mathrm{DMSO}-\mathrm{d}_{6}\right), \delta: \mathrm{ppm}\right)$ of HBPAE macroinitiator: $31.29(-\mathrm{C}-), 36.32\left(2 \mathrm{CH}_{2}-\mathrm{N}\right), 49.56\left(2 \mathrm{CH}_{2}-\mathrm{N}\right), 57.07\left(2 \mathrm{CH}_{2}-\mathrm{OH}\right), 62.64\left(2 \mathrm{CH}_{2}-\mathrm{O}\right), 74.67\left(\mathrm{CH}_{2}\right), 126.00(2 \mathrm{CH}), 128.66$ $(\mathrm{CH}), 135.70(2 \mathrm{CH}), 136.66(\mathrm{CH}), 162.89(3 \mathrm{C}=\mathrm{O}), 167.63(2 \mathrm{C}=\mathrm{O}), 168.95(\mathrm{C}=\mathrm{O})$. 


\subsection{Synthesis of 16-Arm, Star Coil-HBPAE-b-PCL(16 A, S, C-HBPAE-b-PCL) Copolymer with ROP}

16 A, S, C-HBPAE-b-PCL Copolymer was synthesized by HBPAE macroinitiator and $\varepsilon$-caprolactone as tin (II) octoate catalyzer under argon gas at $120^{\circ} \mathrm{C}$. Yield: $98 \mathrm{~g}(88.5 \%) .3417 \mathrm{~cm}^{-1}(-\mathrm{OH}), 2938 \mathrm{~cm}^{-1}$ (Aliphatic $\mathrm{CH}$ ), 1726 $\left.\mathrm{cm}^{-1}(\mathrm{C}=. \mathrm{O}), 1159 \mathrm{~cm} \mathrm{~cm}^{-1} \mathrm{CO}\right)$ in the FT-IR spectrum of $16 \mathrm{~A}, \mathrm{~S}, \mathrm{C}-\mathrm{HBPAE}-\mathrm{b}-\mathrm{PCL}$ copolymer.

${ }^{1} \mathrm{H}-\mathrm{NMR}$ (DMSO-d 6 , ppm) of of $16 \mathrm{~A}, \mathrm{~S}, \mathrm{C}-\mathrm{HBPAE}-\mathrm{b}-\mathrm{PCL}$ Copolymer: $1.25\left(1.25\left(\mathrm{t}, 8 \mathrm{H}, 4 \mathrm{CH}_{2}\right), 1.45-1.52(\mathrm{~m}\right.$, $\left.16 \mathrm{H}, 8 \mathrm{CH}_{2}\right), 2.23\left(\mathrm{~m}, 8 \mathrm{H}, 4 \mathrm{CH}_{2}-\mathrm{C}=\mathrm{O}\right), 2.45-2.47\left(\mathrm{~m}, 8 \mathrm{H}, 4 \mathrm{CH}_{2}\right), 2.48\left(\mathrm{~s}, 2 \mathrm{H}, \mathrm{CH}_{2}-\mathrm{C}=\mathrm{O}\right), 3.32-3.35\left(\mathrm{~m}, 2 \mathrm{H}, \mathrm{CH}_{2}\right), 3.70$ $(2 \mathrm{H}, 2 \mathrm{OH}), 3.94(\mathrm{t}, 8 \mathrm{H}, 4 \mathrm{CH} 2), 4.10\left(\mathrm{~s}, 2 \mathrm{H}, \mathrm{CH}_{2}\right) .5 .72(\mathrm{~s}, 1 \mathrm{H}, \mathrm{CH}), 5.97(\mathrm{~s}, 1 \mathrm{H}, \mathrm{CH}), 6.65(\mathrm{~s}, 1 \mathrm{H}, \mathrm{CH}), 6.71(\mathrm{~s}, 1 \mathrm{H}$, $\mathrm{CH})$.

${ }^{13} \mathrm{C}$ NMR (DMSO-d $6, \mathrm{ppm}$ ) of $16 \mathrm{~A}, \mathrm{~S}, \mathrm{C}-\mathrm{HBPAE}-\mathrm{b}-\mathrm{PCL}$ Copolymer: $24.47\left(4 \mathrm{CH}_{2}\right), 24.94\left(\mathrm{CH}_{2}\right), 25.42\left(4 \mathrm{CH}_{2}\right)$, 25.46(2 $\left.2 \mathrm{CH}_{2}\right), 28.14\left(4 \mathrm{CH}_{2}\right), 32.68(\mathrm{C}), 33.88\left(4 \mathrm{CH}_{2}\right), 34.09\left(\mathrm{CH}_{2}\right), 34.80\left(\mathrm{CH}_{2}\right), 58.80\left(\mathrm{CH}_{2}\right), \quad 61.05\left(\mathrm{CH}_{2}\right), 62.80\left(\mathrm{CH}_{2}\right)$, 64.02 $\left(2 \mathrm{CH}_{2}\right), 65.44\left(\mathrm{CH}_{2}\right), 124.15(2 \mathrm{CH}), 133.33(2 \mathrm{CH}), 173.18(\mathrm{C}=\mathrm{O}), 173.32(2 \mathrm{C}=\mathrm{O}), 173.44(\mathrm{C}=\mathrm{O}), 174.35(\mathrm{C}=\mathrm{O})$, $176.36(\mathrm{C}=\mathrm{O})$.

The Mn, Mw and Mz values obtained by GPC of the 16 A, S, C-HBPAE-b-PCL copolymer are 3370, 4151, 5501 $\mathrm{gmol}^{-1}$. The heterogeneity index $(\mathrm{HI})$ was calculated as 1.23 .

The glass transition temperature $(\mathrm{Tg})$ at $-52^{\circ} \mathrm{C}$ was determined from the DSC thermogram of the $16 \mathrm{~A}, \mathrm{~S}, \mathrm{C}-\mathrm{HBPAE}-$ b-PCL copolymer. Homo-PCL literature has a glass transition temperature of $-60{ }^{\circ} \mathrm{C}$. The $\mathrm{Tg}$ value of the copolymer is greater than the homo-PCL value. An endothermic melting peak was observed at $110^{\circ} \mathrm{C}$ in the DSC thermogram. It was observed that it started to degrade at $358^{\circ} \mathrm{C}$. The TGA thermogram was also observed to degrade at $417^{\circ} \mathrm{C}$.

\subsection{Preparation of Cement Block}

The cement blocks prepared for the experiments were produced in the laboratories of Karadeniz Technical University in accordance with TS EN 196-1, TS EN ISO 15630-1 and TS EN ISO 7500-1 "Cement test methods" standard. The first set, the second set, the third set consist of $120 \mathrm{~mm} \times 25 \mathrm{~mm} \times 15 \mathrm{~mm}$, of $80 \mathrm{~mm} \times 15 \mathrm{~mm} \times 5 \mathrm{~mm}$, of $60 \mathrm{~mm} \times 15 \mathrm{~mm}$ $\times 5 \mathrm{~mm}$ with 6 blocks, respectively. Three different weight ratios $(1 \%, 3 \%, 5 \%)$ of $16 \mathrm{~A}, \mathrm{~S}, \mathrm{C}-\mathrm{HBPAE}-\mathrm{b}-\mathrm{PCL}$ copolymer were added to the mortar samples as included in the test program. The polymer addition was carried out immediately after the addition of the aggregate, and stirring at high speed was continued so that the mixture could be in a completely homogeneous form. Apart from these, blind samples were made.

\subsection{Mechanic Tests}

The compressive strength and the bending resistance tests of the composites were investigated.The cement mortar samples prepared for the experiments were produced in the laboratories of Karadeniz Technical University in accordance with TS EN 196-1, TS EN ISO 15630-1 and TS EN ISO 7500-1 "Cement test methods" standard.The flexural strength $\mathrm{R}_{\mathrm{f}}$ is calculated in N/mm ${ }^{2}$ by using MTS Criterion marka 45 model mechanic test. After bending strength, the two halves of the fractured specimen are subjected to separate compressive strength. Thus, six different values are obtained from a mortar sample poured into three molds at a time.

\section{Results and Discussion}

It was used for improving the mechanic properties of OPC that the new $16 \mathrm{~A}, \mathrm{~S}, \mathrm{C}-\mathrm{HBPAE}-\mathrm{b}-\mathrm{PCL}$ copolymers synthesized from HBPAE as the macroinitiator[1, 2, 3, 4, 5] and $\varepsilon$-CLmonomer with ROP method. Also, HBPAE was a new macrinitiator synthesized by us in Ring Opening(ROP) of $\varepsilon$-CLmonomer. Proton signals of the 16 A, S, C-HBPAE macroinitiator were observed. $2.47\left(\mathrm{~s}, 2 \mathrm{H}, \mathrm{CH}_{2}-\mathrm{C}-\mathrm{O}\right) \mathrm{ppm}$ of the $16 \mathrm{~A}, \mathrm{~S}, \mathrm{C}-\mathrm{HBPAE}-\mathrm{b}-\mathrm{PCL}$ copolymer belongs to the repeating unit of the observed PCLs (-OCH $\mathrm{CH}_{2} \mathrm{CH}_{2} \mathrm{CH}_{2} \mathrm{CH}_{2}-$ ). The methylene-OH at the end of the polymer chain is $3.60(\mathrm{bs}, 2 \mathrm{H}, 2 \mathrm{OH}) \mathrm{ppm}$. The disappearance of the $-\mathrm{OH}$ signal at $3.47(\mathrm{~d}, 2 \mathrm{H}, \mathrm{OH}) \mathrm{ppm}$ of the HBPEA macroinitiator is evidence of the formation of the copolymer. In the ${ }^{13} \mathrm{C}$ NMR spectrum of the HBPAE macroinitiator, the peak of the $\mathrm{OH}-$ $\mathrm{CH}_{2}$ carbon at the end was $57.07 \mathrm{ppm}$, while the $57 \mathrm{C} \mathrm{ppm}$ of the ${ }^{13} \mathrm{C}$ NMR spectrum of the $16 \mathrm{~A}, \mathrm{~S}, \mathrm{C}-\mathrm{HBPAE}-\mathrm{b}-\mathrm{PCL}$ copolymer was not observed. The observation of the carbon signal at $62.64 \mathrm{ppm}$ of the $\mathrm{O}-(-\mathrm{C}=\mathrm{O}-)$ - group formed by the removal of the $\mathrm{H}$ atom at the end of the HBPAE macroinitiator during the polymerization with $\varepsilon$-caprolactone is evidence of ring opening.

The percentage of $16 \mathrm{~A}, \mathrm{~S}, \mathrm{C}-\mathrm{HBPAE}-\mathrm{b}-\mathrm{PCL}$ copolymer incorporated in the cement increases compressive strength and bending resistance. According to the blind sample, it was observed that the pressure and impact strength increased as the amount $16 \mathrm{~A}, \mathrm{~S}, \mathrm{C}-\mathrm{HBPAE}-\mathrm{b}-\mathrm{PCL}$ copolymer increased. It was determined that the bending strength of the cement increased as the amount of $16 \mathrm{~A}, \mathrm{~S}, \mathrm{C}-\mathrm{HBPAE}-\mathrm{b}-\mathrm{PCL}$ copolymer added to the cement increased. MTS Criterion brand 45 model mechanical testing. The new 16 A, S, C-HBPAE-b-PCL-OPC composites containing 16 A, S, C-HBPAE-bPCL additive were prepared for the purpose of improve of Ordinary Portland Cement $(\mathrm{OPC})$ properties. The percentage 
of 16 A, S, C-HBPAE-b-PCL copolymer incorporated in the cement increases residual pressure and impact resistance. According to the blind sample, it was observed that the pressure and impact strength increased as the amount $16 \mathrm{~A}, \mathrm{~S}$, C-HBPAE-b-PCL copolymer increased. It was determined that the bending strength of the cement increased as the amount of $16 \mathrm{~A}, \mathrm{~S}, \mathrm{C}-\mathrm{HBPAE}-\mathrm{b}-\mathrm{PCL}$ copolymer added to the cement increased. The compressive strength and bending resistance of the composite with $16 \mathrm{~A}, \mathrm{~S}, \mathrm{C}-\mathrm{HBPAE}-\mathrm{b}-\mathrm{PCL}$ copolymer (weight, 1\%) is $10.245 \mathrm{~N}$. The compressive strength and bending resistance test of the composite with 1\%, $16 \mathrm{~A}, \mathrm{~S}, \mathrm{C}-\mathrm{HBPAE}-\mathrm{b}-\mathrm{PCL}$ copolymer is higher than the blind sample $(2.901 \mathrm{~N})$. The compressive strength and bending resistance of the composite $16 \mathrm{~A}, \mathrm{~S}, \mathrm{C}-\mathrm{HBPAE}-\mathrm{b}-\mathrm{PCL}$ copolymer (weight, 3\%) is $60.423 \mathrm{~N}$. The pressure and impact strength test of the composite with \% 3, 16 Arms, Star, Flake-HBPAE-b-PCL copolymer is higher than blind sample.

The compressive strength and bending resistance of the composite with, 16 A, S, C-HBPAE-b-PCL copolymer(weight, $5 \%$ ) is $66.357 \mathrm{~N}$. The pressure and impact strength test of the composite with 5\%, $16 \mathrm{~A}, \mathrm{~S}, \mathrm{C}-\mathrm{HBPAE}-$ b-PCL copolymer is higher than the blind sample.

The percentage of $16 \mathrm{~A}, \mathrm{~S}, \mathrm{C}-\mathrm{HBPAE}-\mathrm{b}-\mathrm{PCL}$ copolymer incorporated into the cement increases residual pressure and impact strength. According to the blind sample, as the amount of 16-arm, star, flake-HBPAE-b-PCL copolymer increases, pressure and impact resistance increase. It is observed that the strength of the $16 \mathrm{~A}, \mathrm{~S}, \mathrm{C}-\mathrm{HBPAE}-\mathrm{b}-\mathrm{PCL}$ copolymer added composite material increases as the amount of polymer increases.

\section{References}

[1] A. A. Ibrahim, A. E. S. Abdel-Megied, M. S. Selim, H. H. Darweesh, and M. M. Ayoub, "New Polymeric Admixture for Cement Based on Hyperbranched Poly Amide-Ester with Pentaerythritol Core," Hindawi Publishing Corporation ISRN Materials Science, pp. 1-7, 2013.

[2] D. Kul, L. M. Van Renterghem, M. A. R. Meier, S. Strandman, H. Tenhu, S. S. Y1lmaz, "Encapsulation and release by star-shaped block copolymers as unimolecular nanocontainers," Schubert U.S., Du Prez F.E., Journal of Polymer Science: Part A: Polymer Chemistry, vol. 46, pp. 650-660, 2008.

[3] M. Mısır, T. Öztürk, M. Emirik, S. Yılmaz Savaşkan, "Synthesis of novel tetrahydrofuran-epichlorohydrin [Poly(THF-b-ECH)] macromonomeric peroxy initiators by cationic copolymerization and the quantum chemically investigation of initiation system effects," Journal of Polymer Science: Part A: Polymer Chemistry, vol. 48, pp. 2896-2909, 2010.

[4] T. Öztürk, S. Savaşkan Y1lmaz, B. Hazer, Y. Menceloğlu, "ATRP of Methyl Methacrylate Initiated with A Bifunctional Initiator Bearing Bromomethyl Functional Groups and Synthesis of The Block and Graft Copolymer," Journal of Polymer Science, Part A: Polymer Chemistry, vol. 48, p. 1364, 2010.

[5] T. Öztürk, S. Savaşkan Yılmaz, B. Hazer, "Synthesis of a New Macroperoxy Initiator with Methyl Methacrylate and t-Butyl Peroxy Ester by Atom Transfer Radical Polymerization and Copolymerization with Conventional Vinyl Monomers," Journal of Macromolecular Science, Part A, vol. 45, pp. 1-10, 2008.

[6] S. Ramachandran and S. Krishnamoorthy, Indian J. Tech., 1984.

[7] R. Sidney and J. R. Young, Concrete. Prentice Hall Inc, Englewood Cliffs, p. 671, New Jersey, 1981.

[8] K. Okada and Y. Ohama, "Recent Research and Application of Concrete-Polymer Composites in Japan," 1987. 